\title{
Nurse Perception of Nursing Handover at the University Clinical Hospital in Zagreb
}

1 Slađana Režić

1 Department for Health Care Quality Assurance and Improvement, UHC Zagreb, Croatia

Article received: 11.01.2019.

Article accepted: 15.04.2019.

DOI: $10.24141 / 2 / 3 / 1 / 3$

Author for correspondence:

Slađana Režić

Department for Health Care Quality Assurance and Improvement, UHC Zagreb

Kišpatićeva 12, Zagreb, Croatia

E-mail: sladjana.rezic@gmail.com

Keywords: nursing handover, patient safety, nursing handover guidelines, safety meeting, handover list

\section{Abstract}

Introduction. Nursing handover refers to communication occurring between two shifts of nurses with the specific purpose of handing over information about patients under the nurses' care. Several styles of nursing handover exist, whereas in Croatia written handover is legally required.
Aim. The aim of the study was to examine nurses' perception of the nursing handover: whether nursing handover improves patient safety, whether the content of the handover influences the quality of nursing care and whether the handover is important for continuity of nursing care. The aim was also to determine how the nursing handover is performed, how long it takes and whether written instructions are necessary for the nursing handover.

Methods. The study was conducted between 1 October 2017 and 30 October 2017. The study was conducted on the basis of a questionnaire made specifically for this purpose. The questionnaire consisted of 14 questions. The first part of the questionnaire referred to the participants' demographic data: years of service, age, gender, education level, workplace; the second part of the questionnaire referred to nurses' perception of the nursing handover.

Results. The questionnaire was filled in by 295 nurses. Out of this number, 40 were male and 255 female nurses. The majority of participants finished secondary education and have been working between 11 and 20 years. In most cases, nursing handover is recorded in electronic written form and also at the patient's bedside. Over $90 \%$ of participants feel that the handover contributes to improved patient safety and quality of care.

Conclusion. Nursing handover is recorded in electronic written form, as well as at the patient's bedside on all wards that participated in the study. This form of handover ensures better continuity of care, improves patient safety and reduces loss of vital information. The need to draw up written instructions for the nursing handover was determined. 


\section{Introduction}

Nursing handover refers to communication occurring between two shifts of nurses with the specific purpose of handing over information about patients under the nurses' care (1). Literature cites several different styles of handover: oral, recorded, handover at the patient's bedside and written handover. Each of the above-mentioned handover styles has its advantages and disadvantages. Often individual handover styles are combined. Current research of handover styles is not sufficient to answer the question which handover style is the best. Additional research is needed to determine which handover style to use (2).

In Croatia written nursing handover is used. This way of nursing handover is required by the Law on Nursing (3). Additionally, in all hospitals nursing documentation is kept in electronic form, and so the nursing handover is also written in electronic form. But on most wards, handover at the bedside is also used along with written handover. Thus, the patient is involved in his own care, he gets information about his condition, knows who provides his care and what is planned. Patient satisfaction is greater when handover at the patient's bedside is used $(4,5)$.

The WHO Center for Patient Safety recommends the use of a standardized approach in communication during nursing handover, as well as the use of tools such as the SBAR tool (6).

In literature a strong emphasis is placed on the safety meeting before each handover. The safety meeting is led by the team leader, its purpose being to warn about issues during previous shifts. Issues can include two patients with the same last name, a new form of patient registration, problems with the electronic environment (7).

Some authors emphasize the importance of the handover list. In their opinion, the handover list combined with bedside handover can completely eliminate any loss of information during handover (8).
Aims:

1. To determine, how nurses record the nursing handover

2. To determine how long the nursing handover lasts

3. To compare the observed variables with regard to different clinics, nurses' work experience and education level

4. To examine nurses' perception of whether nursing handover improves patient safety, whether the content of the handover influences the quality of nursing care and whether the handover is important for continuity of nursing care

5. To determine whether a safety meeting was held before each handover

6. To find out whether nurses feel that a written set of instructions for the nursing handover should exist.

\section{Methods}

Respondents were nurses working in shifts in the UHC Zagreb at the following clinics: the Clinic for respiratory diseases Jordanovac, Clinic for thoracic surgery Jordanovac, Clinic for surgery, Clinic for internal diseases, Clinic for psychological medicine, Clinic for neurology, Clinic for oncology, Clinic for otorhinolaryngology and maxillofacial surgery and the Clinic for anesthesiology, reanimation and intensive care. The questionnaire was filled in by 295 nurses. Out of this number, 40 were male and 255 female nurses.

The study was conducted between 1 October 2017 and 30 October 2017. The study was conducted on the basis of a questionnaire made specifically for this purpose. The questionnaire consisted of 14 questions: the first part of the questionnaire related to demographic questions: years of service, age, gender, level of education, place of work; the second part of the questionnaire referred to the nursing handover itself: the way the handover is recorded, how long it lasts, how it affects patient safety, quality and continuity of care, whether a security meeting has been held, whether confidential information is mentioned during handover, if there should be written instructions for the handover. Questions were closed-ended with provided answers. 


\section{Results}

The questionnaire was filled in by 295 respondents, of whom $40(13.6 \%)$ were male and $255(86.4 \%)$ were female. The age range shows that most respondents were between the ages of 20 and 40 . As for the years of service, the highest number of respondents had between 11 and 20 years of work experience (85 respondents/28.8\%), followed by respondents with less than 5 years of work experience (81 respondents/27.5\%). The distribution with regard to education shows that 174 respondents were nurses with secondary school education (59\%), 106 respondents had a bachelor of nursing degree (35.9\%), and 15 respondents had a master of nursing degree (5.1\%). The data is shown in Table 1.

\section{Table 1. Respondents' demographic data

Gender Frequency Percentage

Male $\quad 40 \quad 13.6$ \\ $\begin{array}{lll}\text { Female } \quad 255 & 86.4\end{array}$ \\ Total $295 \quad 100$ \\ Age}

Less than 20 years

$\begin{array}{ccc}20-30 \text { years } & 108 & 36.6 \\ 31-40 \text { years } & 100 & 33.9 \\ 41-50 \text { years } & 45 & 15.3 \\ 51-60 \text { years } & 36 & 12.2 \\ \text { Total } & 295 & 100\end{array}$

Years of service

Less than 5 years $\quad 81 \quad 27.5$

$5-10$ years $\quad 46 \quad 15.6$

$11-20$ years $\quad 85 \quad 28.8$

$21-30$ years $\quad 51 \quad 17.3$

$\begin{array}{lll}\text { More than } 30 \text { years } & 32 & 10.8\end{array}$

Total $295 \quad 100$

Level of education

\begin{tabular}{ccc}
$\begin{array}{c}\text { Secondary school education } \\
\text { Bachelor of nursing }\end{array}$ & 174 & 59 \\
$\begin{array}{c}\text { Master of nursing/graduate } \\
\text { nurse }\end{array}$ & 15 & 35.9 \\
\hline Total & 295 & 5.1 \\
\hline
\end{tabular}

Nurses from nine clinics at the UHC Zagreb took part in the study, as shown in Table 2. It is evident that the majority of respondents were nurses from the Clinic for respiratory diseases Jordanovac - 62 respondents $/ 21 \%$.

\section{Table 2. Respondents according to clinic}

Frequency Percentage

Clinic for

$\begin{gathered}\text { otorhinolaryngology and } \\ \text { maxillofacial surgery }\end{gathered}$
man

Clinic for anesthesiology, reanimation and intensive care

Clinic for respiratory

diseases Jordanovac

Clinic for thoracic surgery

Jordanovac
Clinic for psychological

45

15.3

62

21
medicine

Clinic for surgery

Clinic for neurology

Clinic for internal diseases

Clinic for oncology

Total
9.5

3.4

10.5

7.5

13.2

10.2

100
One of the questions pivotal to the author was the information about the way that the nursing handover is recorded. Most respondents, 173 in number (58.6\%), answered that the nursing handover is recorded in electronic form in the hospital information system, while the handover is done at the patient's bedside. 73 respondents (31.1\%) answered that, along with written handover, oral handover in the nurses' room is also done. Other respondents, 96 in number (32.6\%), record the nursing handover in written form in the information system or a paper notebook. The data is shown in Table 3.

When asked about how long the nursing handover lasts, the largest number of respondents, 132 in number $(44.7 \%)$, responded 10 to 15 minutes, while 118 (40\%) respondents responded more than 15 minutes. The data is shown in Table 4.

Questions related to the nurses' perception of nursing handover show that a large percentage of nurses - over $90 \%$ - believe that nursing handover contributes to improved patient safety, improved quality of care, and better continuity of care. 
Table 3. How is the nursing handover recorded? (Multiple answers are possible)

Written record in the hospital information Frequency Percentage system

Written record in a paper notebook

45

15.3

Written record in the

hospital information

system and a paper

41

13.9 notebook

Written record in the

hospital information

system and oral handover

in the nurses' room

Written record in the

hospital information

system and oral handover
173

58.6

$73 \quad 31.1$ at the bedside

\begin{tabular}{|c|c|c|}
\hline & Frequency & Percentage \\
\hline Less than 5 minutes & 2 & 0.7 \\
\hline 5 - 10 minutes & 43 & 14.6 \\
\hline 10 - 15 minutes & 132 & 44.7 \\
\hline More than 15 minutes & 118 & 40 \\
\hline Total & 295 & 100 \\
\hline
\end{tabular}

As for the question of involvement of the patient in the nursing handover, most respondents, 144 in number $(48.8 \%)$, feel that this depends on the condition of the patient, while 106 (35.9\%) respondents believe that the patient should not be involved in the nursing handover.

When asked about the safety meeting, the majority (112 in number or 38\%) responded that they did not know what a safety meeting was, 101 (34.2\%) respondents responded that they conduct a safety meeting, and $82(27.8 \%)$ respondents said that they do not conduct a safety meeting.

205 (69.5\%) respondents answered yes when asked whether there should be written instructions for the nursing handover. All the results are shown in Table 5.

\section{Table 5. Results of the nurse perception of} nursing handover

Frequency Percentage

Do you feel that the handover contributes to improved patient safety?

\begin{tabular}{ccc} 
Yes & 285 & 96.6 \\
No & 3 & 1 \\
\hline I don't know & 7 & 2.4
\end{tabular}

Do you feel that the content of the handover influences the quality of nursing care?

$\begin{array}{ccc}\text { Yes } & 275 & 93.2 \\ \text { No } & 20 & 6.8\end{array}$

Do you feel that the patient should be involved in the nursing handover?

$\begin{array}{ccc}\text { Yes } & 45 & 15.3 \\ \text { No } & 106 & 35.9 \\ \begin{array}{ccc}\text { Depends on the condition } \\ \text { of the patient }\end{array} & 144 & 48.8\end{array}$

Is confidential information about the patient being mentioned during the handover?

$\begin{array}{lcc}\text { Yes } & 59 & 20 \\ \text { No } & 144 & 48.8 \\ \text { metimes } & 92 & 31.2\end{array}$

Was a safety meeting held before the nursing handover?

$\begin{array}{lll}\text { Yes } & 101 & 34.2\end{array}$

$\begin{array}{lll}\text { No } & 82 & 27.8\end{array}$

I don't know what a safety meeting is

112

38

Do you feel that a written set of instructions for the nursing handover should exist?

$\begin{array}{lcc}\text { Yes } & 205 & 69.5 \\ \text { No } & 90 & 30.5\end{array}$

Do you feel that the nursing handover is important for continuity of nursing care?

$\begin{array}{ccc}\text { Yes } & 293 & 99.3 \\ \text { No } & 2 & 0.7\end{array}$

There is a statistically significant difference between clinics in relation to whether the patient should be involved in the handover. It is evident that at the Clinic for anesthesiology, reanimation and intensive care nurses are least likely to feel that the patient should be involved in the handover. The majority agrees that this should depend on the patient, most of them being nurses from the Clinic for neurology. The results are shown in Table 6.

The Chi-square test result is significant $\left(\chi^{2}=48.36\right.$; $p=0.00$ ). 


\section{Table 6. Attitudes at different clinics with regard to patient involvement in the handover}

\begin{tabular}{|c|c|c|c|c|}
\hline & \multicolumn{3}{|c|}{$\begin{array}{c}\text { Do you feel that the patient should be involved in } \\
\text { the handover? }\end{array}$} & \multirow[b]{2}{*}{ Total } \\
\hline & Yes (\%) & No (\%) & $\begin{array}{l}\text { Depends on the } \\
\text { condition of the } \\
\text { patient }(\%)\end{array}$ & \\
\hline Clinic for otorhinolaryngology & 8 (28.6) & $10(35.7)$ & $10(35.7)$ & 28 \\
\hline $\begin{array}{l}\text { Clinic for anesthesiology, reanimation and } \\
\text { intensive care }\end{array}$ & $2(4.4)$ & $18(40)$ & $25(55.6)$ & 45 \\
\hline Clinic for respiratory diseases & $10(16.1)$ & $23(37.1)$ & $29(46.8)$ & 62 \\
\hline Clinic for thoracic surgery & $1(3.6)$ & $14(50)$ & $13(46.4)$ & 28 \\
\hline Clinic for psychological medicine & $0(0)$ & $10(100)$ & $0(0)$ & 10 \\
\hline Clinic for surgery & $10(32.3)$ & $10(32.3)$ & $11(35.5)$ & 31 \\
\hline Clinic for neurology & $4(18.2)$ & 3 (13.6) & $15(68.2)$ & 22 \\
\hline Clinic for internal diseases & $6(15.4)$ & $13(33.3)$ & $20(51.3)$ & 39 \\
\hline Clinic for oncology & $4(13.3)$ & $5(16.7)$ & $21(51.3)$ & 30 \\
\hline Total & 45 & 106 & 144 & 295 \\
\hline
\end{tabular}

\section{Table 7. Is the mention of confidential information different with regard to the clinic?}

\begin{tabular}{|c|c|c|c|c|}
\hline & \multicolumn{3}{|c|}{$\begin{array}{l}\text { Is confidential information about the patient } \\
\text { mentioned during handover? }\end{array}$} & \multirow[t]{2}{*}{ Total } \\
\hline & Yes (\%) & No (\%) & Sometimes (\%) & \\
\hline Clinic for otorhinolaryngology & $10(35.7)$ & 11 (39.3) & $7(25)$ & 28 \\
\hline $\begin{array}{l}\text { Clinic for anesthesiology, reanimation and } \\
\text { intensive care }\end{array}$ & $10(22.2)$ & 15 (33.3) & $20(44.4)$ & 45 \\
\hline Clinic for respiratory diseases & $11(17.7)$ & $31(50)$ & $20(32.3)$ & 62 \\
\hline Clinic for thoracic surgery & $10(35.7)$ & $13(46.4)$ & 5 (17.9) & 28 \\
\hline Clinic for psychological medicine & $5(50)$ & 0 & $5(50)$ & 10 \\
\hline Clinic for surgery & 0 & $24(77.4)$ & $7(22.6)$ & 31 \\
\hline Clinic for neurology & 0 & $12(54.5)$ & $10(45.5)$ & 22 \\
\hline Clinic for internal diseases & $13(33.3)$ & $10(25.6)$ & $16(41)$ & 39 \\
\hline Clinic for oncology & 0 & $28(93.3)$ & $2(6.7)$ & 30 \\
\hline Total & 59 & 144 & 92 & 295 \\
\hline
\end{tabular}

All clinics significantly more often do not mention patients' confidential information. Confidential data are most often not mentioned at the Clinic for oncology, and are least often not mentioned at the Clinic for internal diseases. They are most often mentioned at the Clinic for psychological medicine (although the answer "yes" and "sometimes" is also equally represented). The results are shown in Table 7.

The Chi-square test result is significant $\left(\chi^{2}=76.03\right.$; $p=0.00$ ).
The analysis regarding the safety meeting shows that the Chi-square test result is significant $\left(\chi^{2}=85.56 ; p=0.00\right)$, implying that the safety meeting is conducted significantly more often at the Clinic for otorhinolaryngology and maxillofacial surgery and the Clinic for oncology. It is least often done at the Clinic for anesthesiology, reanimation and intensive care; the largest number of respondents at this clinic does not know what a safety meeting is. The results are shown in Table 8. 


\begin{tabular}{|c|c|c|c|c|}
\hline & \multicolumn{3}{|c|}{$\begin{array}{l}\text { Was a safety meeting held before the nursing } \\
\text { handover? }\end{array}$} & \multirow[b]{2}{*}{ Total } \\
\hline & Yes (\%) & No (\%) & $\begin{array}{l}\text { I don't know what } \\
\text { a safety meeting } \\
\text { is (\%) }\end{array}$ & \\
\hline Clinic for otorhinolaryngology & $20(71.4)$ & 3 (10.7) & 5 (17.9) & 28 \\
\hline $\begin{array}{l}\text { Clinic for anesthesiology, reanimation and } \\
\text { intensive care }\end{array}$ & $5(11.1)$ & $16(35.6)$ & 24 (53.3) & 45 \\
\hline Clinic for respiratory diseases & $16(25.8)$ & $27(43.5)$ & $19(30.6)$ & 62 \\
\hline Clinic for thoracic surgery & $6(21.4)$ & $8(28.4)$ & $14(50)$ & 28 \\
\hline Clinic for psychological medicine & 0 & 0 & $10(100)$ & 10 \\
\hline Clinic for surgery & $17(54.8)$ & $7(22.6)$ & $7(22.6)$ & 31 \\
\hline Clinic for neurology & $7(31.8)$ & $7(31.8)$ & $8(36.4)$ & 22 \\
\hline Clinic for internal diseases & $8(20.5)$ & 13 (33.3) & $18(46.2)$ & 39 \\
\hline Clinic for oncology & $22(73.3)$ & $1(3.3)$ & $7(23.3)$ & 30 \\
\hline Total & 101 & 82 & 112 & 295 \\
\hline
\end{tabular}

\section{Table 9. Attitude to written instructions according to various clinics}

\begin{tabular}{|c|c|c|c|c|}
\hline & \multicolumn{3}{|c|}{$\begin{array}{c}\text { Do you feel that a written set of instructions for } \\
\text { the nursing handover should exist? }\end{array}$} & \multirow[t]{2}{*}{ Total } \\
\hline & Yes (\%) & No (\%) & & \\
\hline Clinic for otorhinolaryngology & $18(64.3)$ & $10(35.7)$ & 28 & 28 \\
\hline $\begin{array}{l}\text { Clinic for anesthesiology, reanimation and } \\
\text { intensive care }\end{array}$ & 31 (68.9) & $14(31.1)$ & 45 & 45 \\
\hline Clinic for respiratory diseases & $49(79)$ & $13(21)$ & 62 & 62 \\
\hline Clinic for thoracic surgery & $14(50)$ & $14(50)$ & 28 & 28 \\
\hline Clinic for psychological medicine & $6(60)$ & $4(40)$ & 10 & 10 \\
\hline Clinic for surgery & $16(51.6)$ & $15(48.4)$ & 31 & 31 \\
\hline Clinic for neurology & $15(68.2)$ & 7 (31.8) & 22 & 22 \\
\hline Clinic for internal diseases & $32(82.1)$ & 7 (17.9) & 39 & 39 \\
\hline Clinic for oncology & $24(80)$ & $6(20)$ & 30 & 30 \\
\hline Total & 205 & 90 & 295 & 295 \\
\hline
\end{tabular}

Written instructions for nursing handover are considered necessary for the purpose of uniformity and the possibility of tracking and analysis. The Chi-square test result is significant $\left(\chi^{2}=17.63 ; p=0.02\right)$. This means that clinics differ significantly with regard to the answers on the necessity of written instructions for the nursing handover. The results are shown in Table 9.
The Chi-square test result is significant $\left(\chi^{2}=16.61\right.$; $p=0.04$ ) with regard to nurses' attitude towards the involvement of the patient in the handover. The results are shown in Table 10.

The Chi-square test result is not significant $\left(\chi^{2}=7.60\right.$; $p=0.47)$, i.e. there is no significant difference in conducting safety meetings with regard to the respondents' age. The results are shown in Table 11. 


\section{Table 10. Attitudes towards the involvement of the patient in the handover with regard to the} respondents' age

\begin{tabular}{|c|c|c|c|c|}
\hline \multicolumn{5}{|c|}{ Do you feel that the patient should be involved in the handover? } \\
\hline & Yes (\%) & No $(\%)$ & $\begin{array}{c}\text { Depends on the condition of } \\
\text { the patient }(\%)\end{array}$ & Total \\
\hline Less than 20 years & $12(14.6)$ & $24(29.3)$ & $46(56.1)$ & 82 \\
\hline 20 - 30 years & $6(13.3)$ & $14(31.1)$ & 25 (55.6) & 45 \\
\hline $30-40$ years & $8(9.4)$ & $32(37.6)$ & $45(52.9)$ & 85 \\
\hline 40 - 50 years & $14(27.5)$ & $19(37.3)$ & $18(35.3)$ & 51 \\
\hline $50-60$ years & $5(15.6)$ & $17(53.1)$ & $10(31.3)$ & 32 \\
\hline Total & 45 & 106 & 144 & 295 \\
\hline
\end{tabular}

\section{Table 11. Safety meeting with regard to the respondents' age}

\begin{tabular}{|c|c|c|c|c|}
\hline & Yes & No & $\begin{array}{l}\text { I don't know what a safety } \\
\text { meeting is }\end{array}$ & Total \\
\hline Less than 20 years & 28 & 25 & 28 & 81 \\
\hline 20 - 30 years & 14 & 10 & 22 & 46 \\
\hline $30-40$ years & 35 & 23 & 27 & 85 \\
\hline $40-50$ years & 16 & 12 & 23 & 51 \\
\hline $50-60$ years & 8 & 12 & 12 & 32 \\
\hline Total & 101 & 82 & 112 & 295 \\
\hline
\end{tabular}

\section{Table 12. Written instructions with regard to the respondents' age}

\begin{tabular}{|ccc|c|}
\hline & $\begin{array}{c}\text { Do you feel that a written set of instructions for the nursing handover should } \\
\text { exist? }\end{array}$ & No & Total \\
\hline Less than 20 years & Yes & 25 & 81 \\
\hline $20-30$ years & 56 & 12 & 46 \\
\hline $30-40$ years & 34 & 28 & 85 \\
\hline $40-50$ years & 57 & 15 & 51 \\
\hline $50-60$ years & 36 & 10 & 32 \\
\hline Total & 22 & 90 & 295 \\
\hline
\end{tabular}

The Chi-square test result is not significant $\left(\chi^{2}=7.04\right.$; $p=0.95)$, i.e. there is no difference in attitude to written instructions for the handover with regard to the respondents' years in service. The results are shown in Table 12.
The Chi-square test result is significant $\left(\chi^{2}=20.51\right.$; $p=0.00)$. The largest number feels that this solely depends on the patient, especially among respondents with secondary school education and those with the title bachelor of nursing. The results are shown in Table 13. 


\section{Table 13. Attitude towards the involvement of the patient in the handover with regard to the} respondents' education

\begin{tabular}{|ccccc|} 
& \multicolumn{2}{c}{ Do you feel that the patient should be involved in the handover? } \\
& Yes (\%) & No (\%) & $\begin{array}{c}\text { Depends on the condition } \\
\text { of the patient (\%) }\end{array}$ & Total \\
\hline Nurses with secondary education & $14(8)$ & $74(42.5)$ & $86(49.4)$ & $174(100)$ \\
\hline Bachelor of nursing & $26(24.5)$ & $28(26.4)$ & $52(49.1)$ & $106(100)$ \\
\hline Master of nursing/graduate nurse & $5(33.3)$ & $4(26.7)$ & $6(40)$ & $15(100)$ \\
\hline Total & 45 & 106 & 144 & 295 \\
\hline
\end{tabular}

\section{Table 14. The mention of a patient's confidential information with regard to the level of education}

\begin{tabular}{|ccccc} 
& Is confidential information about the patient being mentioned \\
during the handover? & No & Sometimes & Total \\
\hline Nurses with secondary education & 32 & 86 & 56 & 174 \\
Bachelor of nursing & 22 & 51 & 33 & 106 \\
\hline Master of nursing/graduate nurse & 5 & 7 & 3 & 15 \\
Total & 59 & 144 & 92 & 295
\end{tabular}

\section{Table 15. Was a safety meeting held before the nursing handover, with regard to education level?}

\begin{tabular}{|ccccc|} 
& \multicolumn{4}{c}{ Was a safety meeting held before the nursing handover? } \\
& Yes & No & $\begin{array}{c}\text { I don't know what a } \\
\text { safety meeting is }\end{array}$ & Total \\
\hline Nurses with secondary education & 59 & 46 & 69 & 174 \\
\hline Bachelor of nursing & 40 & 27 & 39 & 106 \\
\hline Master of nursing/graduate nurse & 2 & 9 & 4 & 15 \\
\hline Total & 101 & 82 & 112 & 295 \\
\hline
\end{tabular}

\section{Table 16. Written instructions according to education}

\begin{tabular}{|c|c|c|c|c|}
\hline & \multicolumn{4}{|c|}{$\begin{array}{l}\text { Do you feel that a written set of instructions for the nursing } \\
\text { handover should exist? }\end{array}$} \\
\hline & Yes (\%) & No (\%) & Total & Total \\
\hline Nurses with secondary education & $101(58)$ & $73(42)$ & $174(100)$ & 174 \\
\hline Bachelor of nursing & 90 (84.9) & $16(15.1)$ & $106(100)$ & 106 \\
\hline Master of nursing/graduate nurse & $14(93.3)$ & $1(6.7)$ & $15(100)$ & 15 \\
\hline Total & 205 & 90 & 295 & 295 \\
\hline
\end{tabular}

Results pertaining to confidential information about the patient show that there is no significance with regard to education. The Chi-square test result is not significant $\left(\chi^{2}=2.28 ; p=0.68\right)$. The results are shown in Table 14.
According to results, the safety meeting before handover does not show significance with regard to the respondents' education. The Chi-square test result is not significant $\left(\chi^{2}=8.89 ; p=0.64\right)$. The results are shown in Table 15. 
Results with regard to written instructions for handover and the respondents' level of education show significance, mostly among respondents with the highest level of education. Respondents feel that a written set of instructions for the nursing handover should exist. The Chi-square test result is significant $\left(\chi^{2}=26.65\right.$; $p=0.00)$. The results are shown in Table 16.

\section{Discussion}

In Croatia the Law on Nursing requires nursing handover to be recorded in written form. For that reason, it was of great importance to the author to find out how the nursing handover is recorded. The data obtained is very interesting because there is a range of recording types, from written records kept in a notebook, to written handover in electronic form combined with handover at the bedside. As already mentioned, the law only prescribes a written record in electronic form, but nurses recognize the need for oral transmission of patient information. They do this either orally in the nurses' room or at the patient's bedside. According to studies, the nursing handover is one of the key elements of safe and quality care (6). It is also stated that just a written record is not sufficient to pass on all the necessary information about the condition of the patient. The combination of a written record and bedside handover is considered to be the best way to conduct nursing handover.

Fiket in her paper also states that bedside handover is more advantageous than the handover in the nurses' room, that the most common distractor is the medical staff, and that it is necessary to use nursing documentation. The author also states that there is room for improvement (8).

If the nursing handover, in addition to a written record, also takes place at the bedside, then the patient is involved in the transfer of information about his or her condition and this results in greater patient satisfaction. The patient knows which nurses have arrived to the shift, which tests and procedures he or she can expect today, and he or she also has the opportunity to ask additional questions. The question of involvement of the patient in the nursing handover shows that $48.8 \%$ of respondents believe that this depends on the condition of the patient, while $35.9 \%$ of respondents believes that the patient should not be involved in the nursing handover. There is statistical significance regarding the involvement of patients in the nursing handover with regard to the individual clinics. The respondents at the Clinic for anesthesiology, reanimation and intensive care least often feel that the patient's involvement during nursing handover is necessary. This is due to the fact that patients in the aforementioned clinic are, in most cases, sedated, relaxed, and on mechanical ventilation.

Of course, this type of nursing handover includes the additional issue of confidential information. This issue is especially important when the patient is not alone in the room. It is then necessary to protect the integrity of the patient and to respect his or her privacy. The question of confidential information also has a significant Chi-square test result with regard to individual clinics and shows that confidential information is least mentioned at the Clinic for oncology, and most mentioned at the Clinic for psychological medicine (it is important to note that the number of respondents from the Clinic for psychological medicine was small, so it is not possible to draw a reliable conclusion).

A safety meeting is cited as an important element before the handover itself, when information is transferred that is not always related to the patient. This refers to information such as a malfunction of an appliance, an electronic system update, an elevator failure, etc. The safety meeting question provided the information that $38 \%$ of respondents do not know what a safety meeting means. In this case the Chi-square test result is also significant with regard to the individual clinics and shows that the safety meeting is mostly held at the Clinic for otorhinolaryngology and maxillofacial surgery and the Clinic for oncology. It is least often held at the Clinic for anesthesiology, reanimation and intensive care, but there the largest number of respondents does not know what a safety meeting is.

The importance of written instructions about nursing handover should not be the subject of discussion, because having instructions on something helps us do it better. This is also confirmed by studies (9). Interestingly, only $69.5 \%$ of respondents believe that written instructions should exist. 


\section{Conclusion}

The questionnaire was filled in by 295 nurses. The majority of participants finished secondary school education and has been working between 10 and 20 years. The most common way of recording nursing handover is in electronic form, as well as at the patient's bedside. This style of nursing handover ensures better continuity of care, patient safety, and better quality care. Nurses are aware of the benefits of good quality handover and feel that handover represents a key element of the care they provide. The nursing handover in most cases lasts between 10 and 15 minutes.

Conducting a safety meeting before the nursing handover contributes to greater safety for both patients and nurses. If we compare the holding of safety meetings between individual clinics, the Chisquare test result is significant.

As for the issue of the need for written instructions for the nursing handover, all clinics believe that such instructions should exist. This would ensure the uniformity of records and enable an analysis of record quality.

\section{References}

1. Nursing handover for adult patient guidelines. Available from: http://www.wales.nhs.uk/siteplus/861/ Addtional\%201info\%20048.pdf

2. Smeulers M, Lucas C, Vermeulen H. Effectiveness of different nursing handover styles for ensuring continuity of information in hospitalised patients. Cochrane Database Syst Rev 2014. Available from: https:// www.ncbi.nlm.nih.gov/pubmed/24957503.

3. Zakon o sestrinstvu, NN 121/03. Available from: https:// www.zakon.hr/z/407/Zakon-o-sestrinstvu. Croatian.

4. Krsnik J. Utjecaj primopredaje sestrinske službe na kvalitetu zdravstvene njege u Općoj bolnici Vinkovci [diplomski rad]. Zagreb: Sveučilište u Zagrebu, Medicinski fakultet; 2015. Available from: https://urn.nsk. hr/urn:nbn:hr:105:383038. Croatian.

5. Johnson M, Sanchez P, Zheng C. The impact of an integrated nursing handover system on nurses' satisfaction and work practices. J Clin Nurs. 25:257-268. doi: 10.111/jocn.13080.

6. World Health Organization. The Joint Commission: Communication during patient hand-overs. Available from: https://www.who.int/patientsafety/solutions/ patientsafety/PS-Solution3.pdf

7. Safe handover: safe patients. Guidance on clinical handover for clinicians and managers. Available from: www.bma.org.uk/-/.../safe\%20handover\%20safe $\% 2$

8. Fiket M, Družinec I, Karažinec M. Revizija sestrinske primopredaje službe. Plavi fokus. 2013:23-8. Croatian.

9. Chaboyer W, McMurray A, Wallis M, Chang HY. Standard Operating Protocol for Implementing Bedside Handover in Nursing. Australia: Griffith University; 2008. Available from: http://www.safetyandquality.gov.au/wp-content/ uploads/2012/02/SOP-Bedside-Handover.pdf 

U KBC-U ZAGREB

\section{Sažetak}

Uvod. Sestrinska primopredaja službe jest komunikacija koja se odvija između dviju smjena medicinskih sestara čija je specifična svrha predavanje informacija o pacijentima o kojima skrbe medicinske sestre. Postoji nekoliko stilova primopredaje sestrinske službe, a u Hrvatskoj je zakonski obvezna pismena primopredaja.

Cilj. Istraživanje je imalo za cilj ispitati percepciju medicinskih sestara o primopredaji sestrinske službe: pridonosi li primopredaja sestrinske službe većoj sigurnosti pacijenata, utječe li sadržaj primopredaje na kvalitetu provođenja zdravstvene njege te je li primopredaja važna za kontinuitet sestrinske skrbi. Također, cilj je bio utvrditi na koji se način provodi primopredaja sestrinske službe, koliko traje te jesu li potrebne pisane upute za primopredaju sestrinske službe.

Metode. Istraživanje je provedeno u periodu od 1. do 30. listopada 2017. Istraživanje je provedeno putem upitnika izrađenog u tu svrhu. Upitnik se sastojao od 14 pitanja: prvi dio upitnika odnosi se na demografske podatke ispitanika: godine radnog staža, godine života, spol, razina obrazovanja, mjesto rada; drugi dio upitnika odnosio se na percepciju medicinskih sestara o primopredaji sestrinske službe.

Rezultati. Upitnik je ispunilo 295 medicinskih sestara i tehničara. Od toga je broja 40 muških osoba, a 255 ženskih. Najveći je broj ispitanika srednje stručne spreme i radi između 11 i 20 godina. Sestrin- ska primopredaja u najvećem se postotku bilježi u elektroničkom pismenom obliku te uz krevet bolesnika. Više od $90 \%$ ispitanika smatra da primopredaja pridonosi većoj sigurnosti bolesnika te boljoj kvaliteti skrbi.

Zaključak. Primopredaja sestrinske službe bilježi se u elektroničkom pismenom obliku i uz krevet bolesnika na svim odjelima obuhvaćenima istraživanjem. Takav oblik primopredaje osigurava bolji kontinuitet skrbi, veću sigurnost bolesnika i smanjuje mogući gubitak važnih informacija. Pokazuje se potreba za izradom pisanih uputa o primopredaji sestrinske službe.

Ključne riječi: primopredaja sestrinske službe, sigurnost bolesnika, smjernice za primopredaju službe, sigurnosni sastanak, lista primopredaje 